\title{
Influence Of Casting Temperature On The Structural Behavior Of Concrete
}

\author{
Muhammad Arif Panhyar \\ Department of Civil Engineering, \\ Mehran University of Engineering and Technology, \\ Shaheed Zulfiqar Ali Bhutto Campus, Khairpur Mirs', \\ Pakistan \\ Fahad Ali Shaikh \\ Department of Civil Engineering, \\ Mehran University of Engineering and Technology, \\ Jamshoro, Pakistan
}

\author{
Syed Naveed Raza Shah \\ Department of Civil Engineering, \\ Mehran University of Engineering and Technology, \\ Shaheed Zulfiqar Ali Bhutto Campus, Khairpur Mirs', \\ Pakistan
}

\author{
Ashfaque Ahmed Jhatial \\ Department of Civil Engineering, \\ Mehran University of Engineering and Technology, Shaheed \\ Zulfiqar Ali Bhutto Campus, Khairpur Mirs', Pakistan
}

\begin{abstract}
Concrete is the most preferred construction and building material and its demand is not expected to diminish in the near future. The properties of concrete are affected by various factors, one of them is the temperature at casting. This experimental work was carried out in order to study the effect of high temperature on workability, and compressive and flexural tensile strength of concrete. It was found that higher temperatures caused water content evaporation from the mix during casting, causing reduction in workability, but simultaneously increased the strength compared to concrete cast at controlled temperatures).
\end{abstract}

Keywords-structural behavior; temperature; compressive strength; flexural strength; casting temperature

\section{INTRODUCTION}

Concrete is extensively used as a construction material and it is the second highest consumed material around the world [1]. Its popularity is mainly due to its durability, availability, cold resistance, chemical resistance, workability, and flexibility $[2,3]$. Nowadays, concrete consumption in the world is approximated to 2.5 tons per capita per year equal to 17.5 billion tons for a population of 7 billion [4]. Concrete is a composite material and its properties depend on various factors such as proportioning, batching, mixing, transporting, pouring, and curing [5]. Depending on the site conditions, concrete can be mixed manually or with the help of a mixing machine called mixer which can be transported with the help of wheel barrows or pumps. The curing process in concrete is an important factor because curing protects against the loss of needed moisture for hydration, enhances strength and reduces the hardened concrete's permeability. Curing is carried out by various methods, such as: ponding, steam curing, sprinkling water on concrete, covering surfaces with gunny bags, covering surfaces with membrane, and others (providing shades on concrete work, spreading wet sand etc.).
Concrete is a widely used commodity, which can be used in a variety of environments. Concreting, though a relatively easy concept, is less understood sometimes and even small factors like temperature have a big role in its proper and satisfactory performance. Temperature affects the properties of concrete, particularly when it varies during casting and curing. The guidelines for concreting in extreme weather conditions should be properly followed in order to acquire a serviceable product. Concrete is cast under varying surrounding temperatures. Concrete placement in winter is done at low temperatures and curing is done at even lower temperatures. In summer, concrete is frequently poured at high temperatures and cured at much higher temperatures. Casting plays a key role in concrete construction and if not properly brought into action, it will surely have adverse effects on the slump (workability), compressive strength, and flexural tensile strength. Throughout the casting of concrete, various factors should be taken into consideration which may affect its properties, preferably temperature. Temperature directly affects workability, water demand, initial and final setting time, compressive and flexural tensile strength. By inspecting the influence of temperature variation, the behavior of concrete can be more easily identified. Khairpur Mirs' is a city in northern Sindh province of Pakistan, which is considered as an average of the hot climate cities in northern Sindh. The climate remains mostly hot for around 8 months in a year. Furthermore, the temperature of Khairpur Mirs' reached a record high of $49.5^{\circ} \mathrm{C}$ during the heat wave of the 26th of May, 2010. The usual temperature varies approximately from $43.4^{\circ} \mathrm{C}$ to $7.2^{\circ} \mathrm{C}$ in summer and winter respectively [6]. High atmospheric temperature affects concrete's properties by increasing the temperature of fresh concrete and causing a high-water demand, resulting in quick dehydration, which accelerates the initial settling and lowers the long term strength of concrete. High temperature increases the evaporation rate of freshly mixed concrete, resulting in lowering the effective water 
demand and hence lowering the effective water-cement $(\mathrm{w} / \mathrm{c})$ ratio [7].

Keeping concreting continuous either in summer or in winter is important. There is an optimum temperature during the early-life of concrete which optimizes strength at later-ages [8]. In general, temperature was given less priority, it was neglected most of the times. Temperature varies with time and area, therefore, its effects also vary with time and site location. When concrete is fresh, it is desirable to be workable. But sometimes due to conditions at site, the desirable workability is not obtained which results in the form of segregation, bleeding and loss of compressive strength. Also, when there is a high ambient temperature at the casting place, then loss in workability occurs because of the accelerated evaporation process that is adjusted by adding excess water in the concrete mix. Surely, this disturbs the w/c ratio which is directly proportional to concrete's strength. If w/c ratio is increased, it would surely have adverse effects on concrete's strength. Often in summer the temperature may reach $45^{\circ} \mathrm{C}$ at day and $20^{\circ} \mathrm{C}$ at night. This change in temperature will adequately affect concrete's properties. In hot and humid environmental conditions the concrete surfaces could get cracks. Results in [9] show that the serviceability of hardened concrete and the mechanical properties of concrete are significantly affected by temperature. The factors which affect the concrete's strength at high temperature can be divided in to two groups: properties of materials (aggregates, cement) and environmental factors such as temperature, duration of exposure, etc. [10]. Authors in [11] worked on hardened concrete exposed to elevated temperatures [11]. When exposing reinforced concrete structures to risen temperatures, the structure starts deteriorating and could fail [12]. Authors in [13] studied the curing regimes and temperature on the compressive strength of concrete. Authors in [14] studied the effects of curing conditions on concrete's properties. Authors in [15] reported that exposing concrete to risen ambient temperature after casting will have a significant effect on its properties. Long-term behaviors are affected temperature factor and should be investigated [16]. Usually concrete testing is performed under controlled conditions in laboratory. In the field however, the concrete is prepaid and kept in service at a variety of temperatures. The range of concrete use has grown up considerably with many modern constructions being built in countries having a hot and humid climate. Conventionally, the strength properties of concrete have been used as standard for determining its performance, although it is not necessary for concrete to have high strength, but it should have a long service life. It is known that the performance of concrete should be evaluated according to durability and strength under expected surrounding atmospheric conditions. Keeping in view the research work carried out on concrete, only a few were carried out on the effects of casting temperatures on its properties. Most researches were carried out under controlled conditions.

Therefore, an experimental study was conducted in order to learn the effects of Khairpur Mirs' ambient temperature on the workability, compressive and flexural tensile strength of concrete during casting. The results were compared with the ones of conventional specimens.

\section{MATERIALS AND EXPERIMENTAL PROCEDURE}

For this experimental study, Type I Ordinary Portland Cement was used. Locally acquired fine and coarse aggregates had specific gravity of 2.667 and 2.7 respectively. Mix design was done to determine the mix ratio, in order to achieve the target strength according to ACI, which was determined to be 1:2.04:2.74 (1 part cement, 2.04 parts fine and 2.74 parts coarse aggregates), while the $\mathrm{w} / \mathrm{c}$ ratio was 0.62 . To determine the influence of temperature on the properties of concrete, it was cast at two different sites, one under controlled temperature of $26^{\circ} \mathrm{C}$ inside the laboratory, while the other was cast outdoors, in open air where the temperature varied with respect to the time of casting. The casting of concrete was conducted at 1 hour intervals from 11:00 A.M. to 4:00 P.M. (outdoors). To determine the effect of increase in concrete temperature, a total of 6 batches were prepared outside and 1 batch of concrete in the laboratory. For each batch a total of 9 cubes of $150 \mathrm{~mm} \times 150 \mathrm{~mm} \times 150 \mathrm{~mm}$ ( 3 cubes each for 3,7 and 28 days of curing), while 6 beams of $500 \mathrm{~mm} \times 100 \mathrm{~mm} \times 100 \mathrm{~mm}$ ( 3 beams for 7 and 28 days of curing each) were cast and were cured in water for the specified period. The workability was determined according to [17] and was recorded for the wet mix of each batch of concrete. The compressive strength testing of cube specimens was conducted after 3, 7 and 28 days of curing in accordance to [18], while flexural tensile testing was conducted on 7 and 28 days of curing in accordance to [19]. The ambient temperature was recorded during the casting of each batch. The concrete batch cast under controlled temperature was named B1 while the concrete batches cast under uncontrolled temperature and various times were named B-2 to B-7.

\section{RESULTS AND DISCUSSION}

\section{A. Workability}

Workability is directly related to temperature. As the temperature increases, the water available in concrete starts evaporating which reduces workability as shown in Table I. The slump values are also varying with temperature. Figure 1 gives the graphical representation of the variation of slump with respect to time. From the results, it can be observed that the difference in the surrounding temperature has significant impact on workability. The concrete specimens which were cast under controlled temperature (B-1 batch) exhibited the highest slump, but in the outside casting (B-2 to B-7 batches), the workability decreases with increase in temperature. This is attributed to the evaporation of water, which caused the concrete to become dry thus directly effecting workability.

\section{B. Compressive Strength}

From the results shown in Tables II-IV for compressive strength testing at 3, 7 and 28 days respectively, it can be observed that the compressive strength of controlled specimen (B-1 batch) is significantly lower than of the specimens which were cast outside under uncontrolled temperature. This is attributed to the reduction in workability. The $\mathrm{w} / \mathrm{c}$ ratio plays a significant role in achieving specified strength, the higher the w/c ratio the lower the strength that can be achieved. For this experimental work, though the w/c ratio was on the higher side, the difference in strength between the controlled and uncontrolled temperature specimens was significantly high, 
because in uncontrolled environment the water evaporates faster due to rise in temperature causing reduction in workability but simultaneously increasing strength. The variation in compressive strength is illustrated in Figure 2.

TABLE I. WORKABILITY RESULTS OF CONCRETE SAMPLES

\begin{tabular}{|c|c|c|c|}
\hline Batch & Casting time (h) & Temperature $\left.\mathbf{~}^{\mathbf{0}} \mathbf{C}\right)$ & Slump (mm) \\
\hline B-1 & ---- & 26 & 112 \\
\hline B-2 & $11: 00$ AM & 34 & 102 \\
\hline B-3 & $12: 00$ PM & 35 & 98 \\
\hline B-4 & $01: 00$ PM & 37 & 91 \\
\hline B-5 & $02: 00$ PM & 38 & 87 \\
\hline B-6 & $03: 00$ PM & 40 & 82 \\
\hline B-7 & $04: 00$ PM & 42 & 76 \\
\hline
\end{tabular}

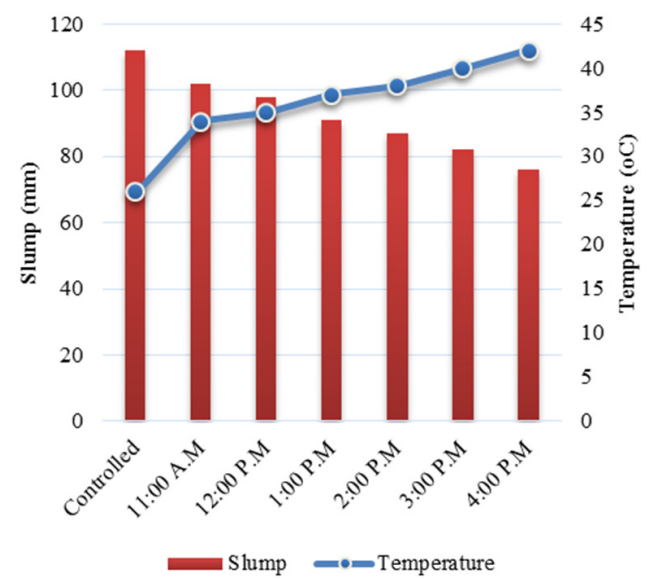

Fig. 1. Slump variation versus temperature and time

TABLE II. AVERAGE COMPRESSIVE STRENGTH ON 3 DAYS

\begin{tabular}{|c|c|c|c|c|}
\hline Batch & $\begin{array}{c}\text { Casting } \\
\text { time }\end{array}$ & $\begin{array}{c}\text { Temperature } \\
\mathbf{~} \mathbf{0}^{\mathbf{0}} \mathbf{C}\end{array}$ & $\begin{array}{c}\text { Avg compressive } \\
\text { strength (MPa) }\end{array}$ & $\begin{array}{c}\text { Increase in strength } \\
\text { w.r.t. control } \\
\text { specimen B-1 (\%) }\end{array}$ \\
\hline B-1 & ----- & 26 & 13.70 & ---- \\
\hline B-2 & $11: 00 \mathrm{AM}$ & 34 & 15.56 & +13.59 \\
\hline B-3 & $12: 00 \mathrm{PM}$ & 35 & 16.10 & +17.52 \\
\hline B-4 & $01: 00 \mathrm{PM}$ & 37 & 16.57 & +20.94 \\
\hline B-5 & $02: 00 \mathrm{PM}$ & 38 & 16.88 & +23.21 \\
\hline B-6 & $03: 00 \mathrm{PM}$ & 40 & 17.38 & +26.86 \\
\hline B-7 & $04: 00 \mathrm{PM}$ & 42 & 17.68 & +29.05 \\
\hline
\end{tabular}

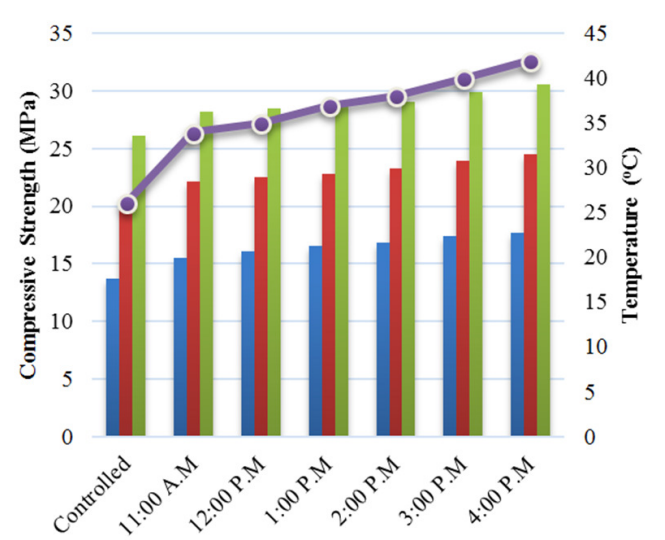

3 Days 7 Days 28 Days $=\bullet$ Temperature

Fig. 2. Variation in compressive strength of concrete
TABLE III. AVERAGE OMPRESSIVE STRENGTH ON 7 DAYS

\begin{tabular}{|c|c|c|c|c|}
\hline Batch & $\begin{array}{c}\text { Casting } \\
\text { time }\end{array}$ & $\begin{array}{c}\text { Temperature } \\
\left.\mathbf{(}^{\mathbf{0}} \mathbf{C}\right)\end{array}$ & $\begin{array}{c}\text { Avg compressive } \\
\text { strength (MPa) }\end{array}$ & $\begin{array}{c}\text { Increase in } \\
\text { strength w.r.t. } \\
\text { control (\%) }\end{array}$ \\
\hline B-1 & ----- & 26 & 19.85 & ---- \\
\hline B-2 & $11: 00$ AM & 34 & 22.11 & $+11.39 \%$ \\
\hline B-3 & $12: 00$ PM & 35 & 22.57 & $+13.7 \%$ \\
\hline B-4 & $01: 00$ PM & 37 & 22.85 & $+15.11 \%$ \\
\hline B-5 & $02: 00$ PM & 38 & 23.32 & $+17.48 \%$ \\
\hline B-6 & $03: 00$ PM & 40 & 23.96 & $+20.70 \%$ \\
\hline B-7 & $04: 00$ PM & 42 & 24.50 & $+23.40 \%$ \\
\hline
\end{tabular}

TABLE IV. AVERAGE COMPRESSIVE STRENGTH ON 28 DAYS

\begin{tabular}{|c|c|c|c|c|}
\hline Batch & $\begin{array}{c}\text { Casting } \\
\text { time }\end{array}$ & $\begin{array}{c}\text { Temperature } \\
\mathbf{(}^{\mathbf{O} C)}\end{array}$ & $\begin{array}{c}\text { Avg compressive } \\
\text { strength (MPa) }\end{array}$ & $\begin{array}{c}\text { Increase in } \\
\text { strength w.r.t. } \\
\text { control (\%) }\end{array}$ \\
\hline B-1 & ---- & 26 & 26.09 & --- \\
\hline B-2 & $11: 00 \mathrm{AM}$ & 34 & 28.19 & $+8.05 \%$ \\
\hline B-3 & $12: 00 \mathrm{PM}$ & 35 & 28.46 & $+9.08 \%$ \\
\hline B-4 & $01: 00 \mathrm{PM}$ & 37 & 28.87 & $+10.65 \%$ \\
\hline B-5 & $02: 00 \mathrm{PM}$ & 38 & 29.11 & $+11.57 \%$ \\
\hline B-6 & $03: 00 \mathrm{PM}$ & 40 & 29.94 & $+14.76 \%$ \\
\hline B-7 & $04: 00 \mathrm{PM}$ & 42 & 30.56 & $+17.13 \%$ \\
\hline
\end{tabular}

\section{Flexural Tensile Strength}

The results of flexural tensile testing are shown in Tables $\mathrm{V}$ and VI for 7 and 28 days of curing respectively, while the variation in flexural tensile strength is shown in Figure 3. The results illustrate that with the increase in temperature during casting, the water content is reduced which causes reduction in workability. The reduction in workability in turn causes some issues while mixing or pouring the concrete into moulds, but it has the advantage of achieving higher strength compared to samples with better workability. This is evident from the results, where the control specimens (B-1 batch), which were cast under controlled temperature achieved higher workability but recorded significantly lower flexural tensile strength compared to the specimens of the B-2 to B-7 batches which were cast under uncontrolled temperature.

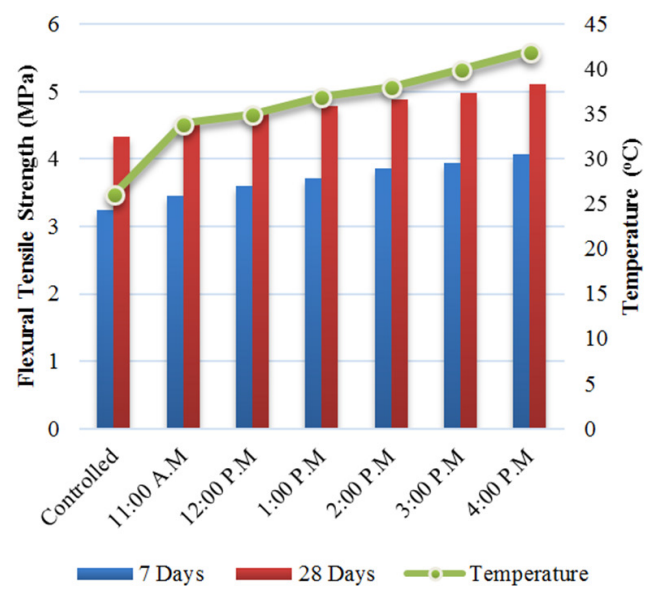

Fig. 3. Variation in flexural strength of concrete 
TABLE V. AVERAGE FLEXURAL TENSILE STRENGTH ON 7 DAYS

\begin{tabular}{|c|c|c|c|c|}
\hline Batch & $\begin{array}{c}\text { Casting } \\
\text { time }\end{array}$ & $\begin{array}{c}\text { Temperature } \\
\mathbf{(} \mathbf{C})\end{array}$ & $\begin{array}{c}\text { Avg flexural } \\
\text { tensile strength } \\
\text { (MPa) }\end{array}$ & $\begin{array}{c}\text { Difference in } \\
\text { strength w.r.t. } \\
\text { control (\%) }\end{array}$ \\
\hline B-1 & ----- & 26 & 3.24 & ---- \\
\hline B-2 & $11: 00 \mathrm{AM}$ & 34 & 3.46 & $+6.96 \%$ \\
\hline B-3 & $12: 00 \mathrm{PM}$ & 35 & 3.60 & $+11.28 \%$ \\
\hline B-4 & $01: 00 \mathrm{PM}$ & 37 & 3.72 & $+15.00 \%$ \\
\hline B-5 & $02: 00 \mathrm{PM}$ & 38 & 3.86 & $+19.31 \%$ \\
\hline B-6 & $03: 00 \mathrm{PM}$ & 40 & 3.94 & $+21.79 \%$ \\
\hline B-7 & $04: 00 \mathrm{PM}$ & 42 & 4.07 & $+25.81 \%$ \\
\hline
\end{tabular}

TABLE VI. AVERAGE FLEXURAL TENSILE STRENGTH ON 28 DAYS

\begin{tabular}{|c|c|c|c|c|}
\hline Batch & $\begin{array}{c}\text { Casting } \\
\text { time }\end{array}$ & $\begin{array}{c}\text { Temperature } \\
\left.\mathbf{(}^{\mathbf{0}} \mathbf{C}\right)\end{array}$ & $\begin{array}{c}\text { Avg flexural } \\
\text { tensile strength } \\
\text { (MPa) }\end{array}$ & $\begin{array}{c}\text { Difference in } \\
\text { strength w.r.t. } \\
\text { control (\%) }\end{array}$ \\
\hline B-1 & ---- & 26 & 4.34 & ---- \\
\hline B-2 & $11: 00$ AM & 34 & 4.53 & $+4.38 \%$ \\
\hline B-3 & $12: 00$ PM & 35 & 4.68 & $+7.83 \%$ \\
\hline B-4 & $01: 00$ PM & 37 & 4.78 & $+10.14 \%$ \\
\hline B-5 & $02: 00$ PM & 38 & 4.89 & $+12.67 \%$ \\
\hline B-6 & $03: 00$ PM & 40 & 4.99 & $+14.98 \%$ \\
\hline B-7 & $04: 00$ PM & 42 & 5.11 & $+17.74 \%$ \\
\hline
\end{tabular}

\section{CONCLUSIONS}

From the results, it can be concluded that:

- The temperature has significant impact on the properties of concrete.

- Controlled temperature allows high workability to be achieved. Uncontrolled temperature tends to cause water content to evaporate, thus causing significant loss in workability.

- The reduction in workability caused by the increase in temperature, has significant impact on the compressive and flexural tensile strength of concrete.

- At the peak recorded temperature of $42^{\circ} \mathrm{C}$, after 3 days of curing, the specimens cast outside were found to have $29.05 \%$ higher compressive strength than the specimens cast at the controlled temperature of $26^{\circ} \mathrm{C}$. After 28 days this increase in percentage was $17.13 \%$.

- The same behavior was observed in flexural strength. After 7 days, the flexural strength of the specimen cast outside at $42^{\circ} \mathrm{C}$ was $25.81 \%$ higher than the one of the specimen cast at the controlled temperature of $26^{\circ} \mathrm{C}$. After 28 days of curing, this increase was $17.74 \%$. This shows that as the temperature increases, the compressive and flexural strength of concrete increase but this diminishes with time.

\section{REFERENCES}

[1] A. A. Jhatial, S. Sohu, N. K. Bhatti, M. T. Lakhiar, R. Oad, "Effect of steel fibres on the compressive and flexural strength of concrete", International Journal of Advanced and Applied Sciences, Vol. 5, No. 10, pp. 16-21, 2018

[2] A. A. Jhatial, W. I. Goh, K. H. Mo, S. Sohu, I. A.Bhatti, "Green and sustainable concrete-the potential utilization of rice husk ash and egg shells", Civil Engineering Journal, Vol. 5, No. 1, pp. 74-81, 2019

[3] I. A. Memon, A. A. Jhatial, S. Sohu, M. T. Lakhiar, Z. Hussain, "Influence of fibre length on the behaviour of polypropylene fibre reinforced cement concrete", Civil Engineering Journal, Vol. 4, No. 9, pp. $2124-2131,2018$

[4] M. S. Islam, M. S. Ali, R. Parvin, "Mechanical properties of concrete made by fine aggregate obtained from dismantled concrete", World Journal of Science and Engineering, Vol. 3, No. 1, pp. 71-88, 2018

[5] A. M. Neville, Properties of Concrete, Wiley, 1996

[6] Climate-Data.org, Khairpur Climate: Average Temperature, Weather by Month, Khairpur Weather Averages, available at: https://en.climatedata.org/asia/pakistan/sindh/khairpur-1228/, accessed at May 10, 2019

[7] J. Ortiz, A. Aguado, L. Agullo, T. Garcia, "Influence of environmental temperatures on the concrete compressive strength: Simulation of hot and cold weather conditions", Cement and Concrete Research, Vol. 35, No. 10, pp. 1970-1979, 2005

[8] P. Klieger, "Effect of Mixing and Curing Temperature on Concrete Strength", ACI 53rd Annual Convention, Dallas, USA, February 27, 1958

[9] K. A. Soudki, E. F. E. Salakawy, N. B. Elkum, "Full factorial optimization of concrete mix design for hot climates", Journal of Materials in Civil Engineering, Vol. 13, No. 6, pp. 427-433, 2001

[10] B. Chen, C. Li, L Chen, "Experimental study of mechanical properties of normal-strength concrete exposed to high temperatures at an early age", Fire Safety Journal, Vol. 44, pp. 997-1002, 2009

[11] Y. Wu, B. Wu, "Residual compressive strength and freeze-thaw resistance of ordinary concrete after high temperature", Construction and Building Materials, Vol. 54, pp. 596-604, 2014

[12] M. Husem, "The effects of high temperature on compressive and flexural strengths of ordinary and high-performance concrete", Fire Safety Journal, Vol. 41, pp. 155-163, 2006

[13] F. Sajedi, "Effect of curing regime and temperature on the compressive strength of cement-slag mortars", Construction and Building Materials, Vol. 36, pp. 549-556, 2012

[14] A. S. A. Ghatani, "Effect of curing methods on the properties of plain and blended cement concretes", Construction and Building Materials, Vol. 24, No. 3, pp. 308-314, 2010

[15] N. A. Memon, F. R. Abro, U. Memon, S. R. Sumadi, "Effect of curing conditions and super plasticizer on compressive strength of concrete exposed to high ambient temperature of Nawabshah, Pakistan", International Journal of Engineering Research, Vol. 3, No. 7, pp. 462464, 2014

[16] G. Yaun, Q. Li, "The use of surface coating in enhancing the mechanical properties and durability of concrete exposed to elevated temperature", Construction and Building Materials, Vol. 95, pp. 375-383, 2015

[17] British Standard Institution, EN 12390-2 (2009): Testing Fresh Concrete. Slump-Test, British Standard Institution, 2009

[18] British Standard Institution, EN 12390-3 (2009): Testing Hardened Concrete. Compressive Strength of Test Specimens, British Standard Institution, 2009

[19] British Standard Institution, EN 12390-5 (2009): Testing Hardened Concrete. Flexural Strength of Test Specimens, British Standard Institution, 2009 